\title{
Review Essay: What Happened to the Study of China in Comparative Politics?
}

\author{
Marie-Eve Reny
}

In 1986, Kenneth Lieberthal observed that the study of China in the United States had had little effect on the evolution of political science. Over twenty years later, its impact on the core debates in comparative politics seems to have been no more significant. Why have some of the most influential books in the study of contemporary Chinese politics not been significant in the discipline of comparative politics? Based on a quantitative overview of forty-two comparative politics syllabi, my argument is twofold. First, China scholarship has isolated the study of Chinese politics by primarily publishing in area journals, building analyses around debates exclusive to Chinese politics, and generating knowledge with limited contemplation of its potential for generalization outside China. Second, comparative politics seems to have been caught in a "democratic prism," which has impeded scholars' ability to adapt some of the debates to empirical changes associated with China's rise and development. KeYwords: China studies, comparative politics

In 1986, KenNeth LIeBerthal published an ARTICle in PS: POlitical Science and Politics that started from the observation that the study of China in the United States had had little effect on the evolution of political science. Years later, the impact of China studies on the core debates in comparative politics seems to have been no more significant. This prima facie strikes one as surprising in light of Paul Pierson and Theda Skocpol's (2002) claim that one of the goals of comparative politics is to address big, substantive questions about politics at different points of world history. China has been undergoing dramatic internal changes in its society and economy in the past thirty years, and this has had significant political implications domestically and internationally. China's rapid rise as an economic power and increasing political influence have impacted all countries' domestic and foreign policies, directly or indirectly. Yet, 
despite the significance of China's development for world politics, the scholarship that emerged about this process of transformation had remarkably little effect on the dominant debates in the discipline of comparative politics. Why have some of the most influential books in the study of contemporary Chinese politics not been significant in comparative politics? Moreover, how has the low "visibility" of China studies impacted our understanding of the discipline?

Many of us would emphasize the field's eurocentrism and post-1950s US hegemony as the main factors behind the lack of influence of Chinaderived findings. However, such an assumption may only be true to some extent given the importance that the studies of Latin American, African, and post-Soviet societies had on the emergence and evolution of several core subliteratures in comparative politics. ${ }^{1}$ This also suggests that area studies do not necessarily come at the expense of "cross-fertilization with theoretically relevant scholarship ... in the discipline," as originally suggested by Kenneth Lieberthal (1986, 71), among others. In a similar vein, some scholars may be tempted to explain the importance given to the study of areas other than China as resulting from historical geostrategic incentives on the part of Western powers. Accordingly, colonial legacies and the interest of the West to follow closely the politics of former colonies have made the study of Latin American and African contexts prominent since the 1960s and 1970s. Similarly, the Cold War allowed for the development of an influential epistemic community on the Soviet Union in the United States and Europe, which may have positively impacted the visibility of studies of post-Soviet states after $1989 .{ }^{2}$ While this argument is appealing, it does not explain why in light of changes in geopolitical dynamics due to China's economic and political rise, and despite a numerously significant and growing community of China experts in comparative politics and in emerging political economy studies, China as an empirical terrain is not more acknowledged in the discipline. Finally, another explanation could be that China's low visibility in the field stems from its own historical circumstances, such as the inability to do research in the country during most of the Maoist period ${ }^{3}$ and the fact that China is a late developer. This argument could not, however, explain why the study of other historically slow developers, like post-Soviet countries, has marked the recent evolution of the discipline.

I argue that China's absence in the core comparative politics debates stems both from the ways in which studies of the country have been analytically and conceptually framed, and from some of the obstacles the discipline faces in adjusting its debates to new empirical realities and puzzles. On the one hand, China scholarship has empirically and analytically 
isolated the study of Chinese politics in three ways: first, it has published predominantly in area studies journals at the expense of subfield ones; second, analyses of Chinese politics have been built primarily around theoretical debates exclusive to the literature on Chinese politics and, as a result, opportunities to formulate questions of broader, comparative scope have been missed; third, and not unrelated to the second point, knowledge has been generated from the study of China with little contemplation of its potential for generalization outside the single case. On the other hand, the discipline of comparative politics seems to have been caught in a "democratic prism," which has impeded comparativists' ability to adapt some of the core debates to empirical changes associated with China's rise and development.

My analysis is divided into three sections. First, I discuss the relative importance of China studies in the discipline, based on a quantitative overview of the number and frequency of sources using China as a case, across forty-two comparative politics syllabi. Second, I elaborate on the ways in which China scholarship ${ }^{4}$ has contributed to the isolation of China studies. Third, I address how the discipline has been caught in a democratic prism, resulting in the disregard of China's potential as an empirical terrain for the exploration of new comparative puzzles.

\section{Where Is China in Comparative Politics Syllabi?}

To assess the relative importance of studies of Chinese politics on the discipline's core debates, I collected a sample of forty-two comparative politics syllabi from US universities and liberal arts colleges between 2000 and 2010. Course outlines are a helpful tool in assessing whether China as a case study has shaped the evolution of debates in comparative politics, for three reasons. First, syllabi are meant to constitute a synthesized list of the core contributions in the discipline, and instructors are asked to select the analyses that best characterize its evolution. Hence, outlines are highly revealing of comparativists' understanding of what the important debates have been and who the makers of such debates are. This understanding remains rather consistent across most syllabi and universities in the sample, with the exception of course outlines whose structure is area-based rather than built around themes and that predominantly assign comparative politics textbooks as opposed to peer-reviewed articles or academic books. Consistency was reflected not only in how instructors divided the core themes of the discipline, but also in the contributions they listed on their syllabi. Furthermore, it was reflected in the subjects for which they thought China was relevant. Themes for 
which China readings were recurrent in syllabi were political (i.e., communist or authoritarian) regimes as well as social movements and revolutions. Second, while course outlines are meant to provide a synthesis, they are also generally designed to be comprehensive. Their latter trait makes them useful in comparing the influence of China-derived findings on the discipline against findings derived from other countries or regions of the world. Third, the data in course outlines can be measured and quantified easily, and the latter procedure can be conducted with limited risks of creating additional sources of bias into the primary data.

All syllabi were nonrandomly gathered online. Outlines were accessed via Google, by typing in keywords like comparative politics syllabi and comparative politics course outline $(s) .{ }^{5}$ The criteria for selecting syllabi as part of my sample were the following. First, course outlines had to be from the top fifty universities and liberal arts colleges in the United States according to the 2010 U.S. News \& World Report ranking. ${ }^{6}$ Second, they had to cover the discipline of comparative politics at large, not one or a few subliteratures within it. Hence, a course that would have been titled "Comparative Politics: Political Parties and Party Systems" would have been automatically excluded from the sample. Provided that they were thematically comprehensive, courses could be at the undergraduate and graduate levels. Out of forty-two syllabi, sixteen were at the graduate level and twenty-six were undergraduate course outlines. Third, the comparative politics courses had to be taught by non-China scholars. Out of forty-two syllabi, thirteen were designed by specialists of European and North American politics, five by Africanists, nine by Latin Americanists, three by South Asianists, four by specialists of postSoviet countries including Russia, two by East and Southeast Asianists, one by a specialist of the Middle East, and five by scholars with more than one area of expertise, excluding China. The rationale for such selection criteria is simple. The purpose of this project is to assess how significantly the study of China is considered to have shaped the core debates in our discipline. It is likely that the empirical biases and preferences of China scholars would most likely lead them to overestimate the critical importance of China studies in those debates. In any case, I assume that comparative politics syllabi by China scholars would be biased in favor of readings on Chinese politics and could misrepresent the actual significance of China studies in the discipline. It is not impossible that selecting syllabi from specialists of other areas could have introduced reversed forms of biases in my sample. There are two reasons why I believe that is unlikely. First, studies of Latin America have been crucial to generating key findings in the literatures on democratization, as 
well as on modernization and dependency theories, in ways that a country like China has not. It is thus not abnormal that some themes in our syllabi may be overrepresented by some areas of the world as opposed to others. Second, the number of Africa and Latin America readings is relatively even within and across syllabi, regardless of instructors' area of specialization. For eleven Latin America readings in a 2002 University of Michigan course outline, there were eleven analyses using empirical data derived from the study of Africa and eight sources based on postSoviet case studies. For three Latin America readings in a Middlebury College syllabus, there were four Africa readings and four sources using post-Soviet cases. Moreover, while some syllabi had more analyses of the instructor's area of expertise, the numerical gap between the latter and studies of other areas was relatively insignificant. For instance, in a 2008 Harvard syllabus prepared by a Latin Americanist, I found twenty-one studies of Latin America, along with eighteen studies of Africa and sixteen of post-Soviet states. That same course outline contained four readings on China.

In my sample of forty-two syllabi, I found a total of thirty-five China-derived sources spread out across nineteen course outlines. Most of these sources did not appear in more than one syllabus, which suggests the potential lack of consensus as to what the major China contributions in the discipline are. ${ }^{7}$ The sample, however, contained a much larger number of analyses based on Latin American, African, and postSoviet case studies. ${ }^{8}$ While 136 analyses were derived from the study of Latin America spread out across thirty-two syllabi, 110 were based on African cases and spread across twenty-eight outlines, and ninety-eight articles using post-Soviet countries were found among twenty-nine syllabi. Additionally, studies of the Middle East, a region that has been the object of greater research in international relations than in comparative politics, exceed the number of China readings. Eighteen syllabi included a total of fifty sources analyzing Middle East cases. ${ }^{9}$ Finally, twentyeight syllabi contained a total of seventy-one analyses of Asian countries other than China. (See Table 1.)

Out of forty-two outlines, five contained a section on China. Moreover, most of the syllabi partly designed on the basis of geographic areas assigned not only articles or books written by China scholars per se, but also China readings derived from comparative politics textbooks edited and written by comparativists. ${ }^{10}$ Out of the nineteen syllabi that contained China-derived analyses, two included exclusively chapters on China from a comparative politics textbook, and three of them contained both book chapters by comparativists and analyses by China specialists in 
Table 1 Syllabi with Case Studies

\begin{tabular}{lcc}
\hline & $\begin{array}{c}\text { Syllabi Containing } \\
\text { Region-based Case Studies }\end{array}$ & $\begin{array}{c}\text { Case Studies } \\
\text { per Region }\end{array}$ \\
\hline China & 19 & 35 \\
Asia (excluding China) & 28 & 71 \\
Latin America & 32 & 136 \\
Africa & 28 & 110 \\
Middle East & 18 & 50 \\
Post-Soviet states & 29 & 98 \\
\hline
\end{tabular}

peer-reviewed journals. Moreover, it is worth mentioning that out of the thirty-five sources using China as a case study, Theda Skocpol's States and Social Revolutions (1979) appeared six times, and Barrington Moore's Social Origins of Dictatorship and Democracy (1966) appeared four times. Hence, at least ten sources out of thirty-five using China as a case were not from China specialists per se but from comparativists who used China as one of several other cases in macrohistorical analyses. ${ }^{11}$

However, because most of the available syllabi online were from the year 2000 onward, I am unable to determine whether the extent to which China studies are covered in my sample constitutes an improvement from the degree of China coverage in the 1980s or early 1990s. (See Table 2.)

According to my sample, there seems to be no clear sign that studies of Chinese politics have been increasingly considered in the design of comparative politics syllabi since 2000. While the sample contains twelve China sources between 2000 and 2005, as opposed to twentythree between 2006 and 2010, this discrepancy may be more symptomatic of an uneven number of syllabi during those two periods than of an actual increase in the representation of China studies in comparative politics. Indeed, my sample contains twelve syllabi dating from the 2000-2005 period, and thirty from the 2006-2010 period. Nonetheless, if the 2006-2010 data were to be representative of an increase in the visibility of China studies in the overall discipline, the observations made in the present analysis remain relevant. In contrast to the study of other developing areas in the world, analyses of China have so far played a minor role in shaping the debates in comparative politics.

The low representation of China studies in comparative politics syllabi does not seem to be related to a potential bias against Asian case studies. Indeed, out of the twenty-three syllabi that did not contain China sources, fourteen included readings using other Asian countries as case studies. Analyses that are most recurrent are the ones derived from the 
Table 2 China Analyses by Year

\begin{tabular}{lccc}
\hline Years & $\begin{array}{c}\text { Number of } \\
\text { Syllabi per Year }\end{array}$ & $\begin{array}{c}\text { Number of } \\
\text { China Analyses }\end{array}$ & $\begin{array}{c}\text { Number of } \\
\text { Syllabi Containing } \\
\text { China Analyses }\end{array}$ \\
\hline 2000 & 1 & 1 & 1 \\
2001 & 0 & 0 & 0 \\
2002 & 3 & 4 & 2 \\
2003 & 0 & 0 & 0 \\
2004 & 4 & 2 & 2 \\
2005 & 4 & 5 & 3 \\
2006 & 7 & 8 & 3 \\
2007 & 5 & 5 & 2 \\
2008 & 9 & 5 & 2 \\
2009 & 6 & 3 & 1 \\
2010 & 3 & 2 & 3 \\
\hline
\end{tabular}

literature on the developmental state using South Korea and Japan as case studies; the literature on contentious politics using James C. Scott's Weapons of the Weak (1985), Scott's Moral Economy of the Peasant (1976), or Samuel Popkin's The Rational Peasant (1979), all based on Southeast Asia as the main empirical terrain; ${ }^{12}$ and studies of ethnic politics and democracy in India. If the study of many South Asian, Southeast Asian, and East Asian countries have shaped the evolution of comparative politics debates, why have China studies had little impact on the discipline?

\section{China Studies: An Isolated Field}

Few scholars seem to have seized the opportunity to frame their analyses of Chinese domestic politics in comparative terms. Among the exceptions to the rule ${ }^{13}$ is Kellee S. Tsai (2006), who sheds light on the causal mechanisms and processes underlying institutional resilience in China, emphasizing the role of "adaptive informal institutions" in endogenous institutional change. In doing so, the author makes an important contribution to the literature on neoinstitutionalism, supporting the claim of Douglass North (1990) that informal institutions can ensure the stickiness of formal institutions and stability of organizations. Most important, Tsai succeeds in showing that beyond the ability of informal rules to ensure the stability of particular models of capitalism,,${ }^{14}$ they can also help ensure the sustainability of political regimes. Similarly, in an attempt to assess the third generation of China scholarship, Bruce Gilley (2011) questions the 
relevance of alternative approaches to the state-centered perspective that have been used to understand politics in China's reform era. The author argues that despite three decades of reform, the state remains the most important unit of analysis to understand politics in the country and questions the assumptions of Robert A. Dahl (1971) and Samuel Huntington (1968) according to which the state's loss of control over resources also leads to a decline in its control over politics. Gabriella Montinola, Yingyi Qian, and Barry Weingast (1995) also make a significant contribution to existent studies of the economic role of political institutions in the discipline, in calling for special attention to a particular kind of federalism illustrated by the Chinese case-namely, market-preserving federalismwhich has defied conventional wisdom in ensuring China's economic growth. ${ }^{15}$ Dorothy Solinger (1991) made another important comparative contribution. Her From Lathes to Looms draws on the works of Mancur Olson (1971), Theda Skocpol (1995), and Peter Katzenstein (1978), among others, to challenge the assumption that industrial policy in China should best be understood within the context of an authoritarian model of politics (Solinger 1991, 16). Minxin Pei (2006a) takes a comparative angle by challenging modernization theory à la Adam Przeworski and Fernando Limongi (1993), suggesting that there are conditions under which a country's "rising prosperity can actually remove the pressure for democratization, and frustrations with the slow speed of economic reform may force leaders to seek political reforms" (Pei 2006a, 19). Additionally, to introduce the concept of "decentralized predation," Pei draws on the insights from the study of East Asian political economy, citing Peter Evans (1995) and Robert Wade (2000), and from the literature on collective action, citing North (1990) and Olson (1996), among others. Finally, Political Transitions in Dominant Party Systems: Learning to Lose (Friedman and Wong 2009) offers a wide range of country-specific case studies, including China, in an attempt to address the consequences of dominant political parties' prospects of losing.

Some quantitative China scholars have also built their analyses on theoretical contributions in the discipline. Melanie Manion's (2006) analysis of the impact of grassroots elections on popular perceptions that local leaders are trustworthy in China draws on Kurt Weyland's (1998) analysis of the effect of economic and political liberalization on the rise of opportunities for corruption in Latin America, and on Daniel Treisman's (2000) findings that democratic institutions require decades before translating into lower levels of perceived corruption.

Despite some efforts at framing analyses of China in comparative terms, China scholarship seems to have isolated the study of Chinese 
politics in three ways. First, scholars have published predominantly in area journals at the expense of subfield ones. Second, analyses of China have been built around theoretical debates that are exclusive to the literature on Chinese politics. In doing so, the scholarship has missed the opportunity to link questions that are specific to China to broader puzzles that could help fill some analytical gaps in the discipline. Third, and not unrelated to the preceding, analyses have generated China-derived knowledge with litthe contemplation of its potential for generalizability outside a single case.

First, most scholars of China have predominantly published in area journals at the expense of subfield journals. Among the China-based journals ${ }^{16}$ they have prioritized are China Quarterly, Journal of Contemporary China, China Journal, and Modern China. Among the Asia-related journals are Asian Survey and Journal of Asian Studies. Scholars have also published more chapters in edited volumes specific to China as opposed to volumes comparing country cases on the basis of a particular theme. To support the preceding, I have selected the list of publications of some of the most influential China scholars ${ }^{17}$ in political science and compared the number of articles published in China/Asia journals with that of contributions in subfield journals. (See Table 3.)

Among the eight identified China scholars, none had half or more than half of their publications published in subfield journals or comparative theme-oriented edited volumes. Two out of eight scholars published $40-45$ percent of their articles and/or book chapters in subfield journals or edited volumes, ${ }^{18}$ four published $30-39$ percent of their works in similar journals or volumes, and two published 20-29 percent of their articles and chapters for an audience of comparativists. ${ }^{19}$

Table 3 Publications by China Scholars

\begin{tabular}{cccc}
\hline China Scholars & $\begin{array}{c}\text { Publications in } \\
\text { Subfield Journals } \\
\text { and/or Edited Volumes }\end{array}$ & $\begin{array}{c}\text { Publications in } \\
\text { China/Asia Journals } \\
\text { or Edited Volumes }\end{array}$ & $\begin{array}{c}\text { Percentage of } \\
\text { Publications in } \\
\text { Subfield Journals } \\
\text { and Volumes }\end{array}$ \\
\hline A & 6 & 15 & 40 \\
B & 3 & 13 & 23 \\
C & 6 & 24 & 25 \\
D & 16 & 41 & 39 \\
E & 6 & 14 & 43 \\
F & 6 & 17 & 35 \\
G & 23 & 71 & 32 \\
H & 6 & 16 & 37.5 \\
\hline
\end{tabular}


Table 4 Number of Scholars with Proportion of Publications in Subfield Journals and Volumes

\begin{tabular}{lcccccc}
\hline & \multicolumn{5}{c}{ Publications in Subfield Journals and Edited Volumes } \\
\cline { 2 - 7 } $\begin{array}{l}\text { Number of Scholars } \\
\text { by Region }\end{array}$ & $40-49 \%$ & $50-59 \%$ & $60-69 \%$ & $70-79 \%$ & $80-89 \%$ & $90-100 \%$ \\
\hline Latin America & 1 & 0 & 2 & 2 & 0 & 0 \\
Africa & 1 & 0 & 2 & 1 & 0 & 1 \\
Post-Soviet states & 2 & 1 & 2 & 0 & 0 & 0 \\
Middle East & 3 & 0 & 1 & 0 & 1 & 0 \\
\hline
\end{tabular}

The reality appears to be different for Latin Americanists and Africanists (see Table 4). Among five of the most influential scholars of Latin America ${ }^{20}$ two published over 75 percent of their articles and book chapters in subfield journals and edited volumes, and two published 60-70 percent of their works in such journals and volumes. In the fifth case, 41 percent of publications were field-related. Among five influential Africanists, the lowest proportion of publications targeting a comparativist audience was 47 percent, and the highest one was 93 percent. In the three other cases, the proportion varied between 64 and 77 percent. Middle East and post-Soviet scholars included in my sample also seem to have dedicated a larger proportion of their works to a comparativist audience. In both cases, the lowest proportion of theme-oriented publications was not inferior to 40 percent. It is true that China scholars' low rate of subfield-oriented publications could be the result of reasons other than their choosing to publish almost exclusively in area studies journals. For instance, authors could have submitted manuscripts that may have been rejected. This hypothesis would be difficult to test in light of the anonymity of manuscript submission processes. Nonetheless, even in light of other potential reasons for China scholarship's limited comparative publications, the numbers cited seem to suggest that specialists of other world regions publish more in subfield journals than sinologists do.

A predominant focus on area-based publications may have impeded the visibility of China analyses in the overall discipline in two potential ways. On the one hand, one would assume that comparativists are unlikely to consult China or Asia journals if they do not have a particular interest or reason to do so. ${ }^{21}$ Conversely, comparativists may be more likely to read an analysis of China if published in a subfield journal or in one of the main journals of the discipline that they consult regularly. On the other hand, the need to discuss the relevance of findings beyond the 
China case may be less important a criterion for publication in China journals than in subfield ones.

Second, rather than build their literature reviews and theoretical frameworks around some core comparative questions, China scholarship seems to have framed analyses around theoretical debates that are exclusive to the literature on Chinese politics. Jing Huang (2000), in his Factionalism in Chinese Communist Politics, illustrates this point well as he seeks to explain the existence of factionalism in the Chinese Communist Party (CCP), whose rule as a Leninist party depends on its unity. It starts from the assumption that factionalism has been understudied in the literature on China, drawing on the few existent contributions on the matter, namely those of Andrew Nathan (1973), William Whitson (1973), and Lucian Pye (1981). In so doing, Huang sets the stage for an audience to his book that is likely to be composed of sinologists interested in leadership questions. Had the author organized the framework around the lack of research on factionalism in nondemocratic or "hybrid" regimes, his audience would have most likely been more diverse. Similarly, in Remaking the Chinese Leviathan, Dali Yang (2004) introduces a review of the literature that centers on debates among China specialists. In discussing the relationship between state and business in a broader context of reforms, the author refers to the contributions of Susan Shirk (1993), Jean Oi (1992), Marc Blecher and Vivienne Shue (1996), and Xiaobo Lü (2000), among several others. Yet the potential insights or gaps within the broader comparative literature on the relationship between business interests and democratic and nondemocratic states could have been explored further. Despite their primary orientation around China debates, some analyses incorporate elements of comparison. In conclusion, Yang (2004) compares China's governance reforms with those of Russia and the United States. However, comparison does not help address the author's actual puzzle22 and as such remains secondary to the purpose of the analysis.

Moreover, in building their theoretical frameworks around debates in the China field, scholars have missed the opportunity to formulate research questions that may have helped fill some analytical gaps in the discipline. Thinking less broadly or comparatively has also affected how sinologists have understood China. For instance, Anne-Marie Brady's (2008) empirically rich Marketing Dictatorship offers little insight into how the functioning of current Chinese government propaganda is the- 
oretically or conceptually similar or different from that of other current or past authoritarian or totalitarian regimes. Doing so would have allowed the author to explore some important comparative questions, such as under what conditions can current nondemocratic regimes succeed in adjusting their propaganda strategies to the changing dynamics of globalization in order to better ensure their own resilience? Compared to other such countries, has China been more successful and, if so, why?

In a similar vein, in her attempt to explain regime resilience, Elizabeth Perry $(2007,15)$ emphasizes that the leadership has successfully "adapted Maoist tactics to cope with contemporary [societal] challenges," drawing interesting linkages between Maoist campaigns and the central government's recent struggle against the Falun Gong in the 1990s and 2000s, as well as its battle against the SARS outbreak (Perry 2007, 1415). While the author compares experiences across time in China, some insightful parallels or differences could be drawn between her study and that of transitions that failed, where new institutions were created despite enduring remnants of the old regime. ${ }^{23}$

Finally, Oi (1999) asks an important question-What accounts for local government officials' leading role in the pursuit of rapid industrial growth in China's rural areas?-and argues that reforms were designed in ways that allowed the promoters of economic development to consolidate their official power rather than weaken it. However, the question could have been situated within the larger debates about state-led development. While the author briefly alludes to the existent literature on the developmental state, little space is dedicated to explaining how the study constitutes an important contribution in those debates, as well as how China may constitute an empirical anomaly or share similarities with other newly industrializing countries (NICs), and why it may do so.

Third, several China scholars have generated China-derived knowledge with little contemplation of its potential for generalizability outside their single case. This is particularly manifested in the linkages they draw between Chinese empirics and existent debates in the discipline, which often serve the primary purpose of understanding China. Oi (1999), in her compelling discussion about the distinctive feature of state-led development in China, in which local governments take the lead in implementing reforms, draws on Evans's (1995) claim that what matters is not how much the state intervenes, but how it does so. The author leaves unaddressed, though, the conditions under which her concept of "local state corporatism" could be applicable beyond the China case. 
Shirk's Political Logic of Economic Reform in China challenges the assumption that "communist systems usually ignore the institutional framework of policy-making" where it is taken for granted that "institutional rules and lines of authority are irrelevant." Indeed, rather than being a game played only by a few leaders, Shirk makes the important claim that "policy-making in China has become a pluralistic process involving hundreds of officials from various Communist Party and government departments" (Shirk 1993, 7). The author emphasizes that there are five features of Communist institutions that influence the behavior of officials who make economic policy decisions. These are authority relations, leadership incentives, the bargaining arena, enfranchised participants in policy deliberations, and the rules of collective choice (Shirk 1993, 10). This book strikes one as holding the potential for a crucial contribution to the comparative literatures on policymaking and regime types. It could have started with an analysis of the conceptual and theoretical flaws in studies that assume that the "policy-making process" in nondemocratic regimes is irrelevant, and it could have explained how the latter assumption may have contributed to our overall misunderstanding of decisionmaking in authoritarian regimes. In other words, it could have addressed more explicitly why understanding the complexity of the policymaking process in an autocratic regime like that of China matters as much as it does in democratic systems.

Finally, in the context of a broader study of the reasons for regime resilience in China, Perry (2007) suggests that social mobilization is not as destabilizing a factor as it may have been in other nondemocratic settings (Huntington 1991), including the Soviet Union, because it has been an important component of Chinese politics throughout a part of history, ${ }^{24}$ and because protesters in today's China adopt a "rightful" 25 language to frame their claims, just as they "borrowed the hegemonic language of class in pressing their demands" under Mao (Perry 2007, 21). This distinction opens the door to possibilities for analyses that center on explaining why factors like a vibrant civil society may be an obstacle to or promoter of autocratic regime resilience. Perry's analysis of the reproduction of notions of "rules consciousness" among the Chinese population from the Maoist era to the current period may have benefited from greater visibility had it been framed in the context of a study comparing the evolution of civil society's ways of pressing the state and its impact on regime resilience or change, using China and other cases featuring potentially similar tendencies or opposite ones. ${ }^{26}$

Harry Harding (1984) saw as one of the main obstacles to the comparative study of China in the 1970s assumptions about China's exceptionalism as found in Pye's Dynamics of Chinese Politics (1981) as well 
as in the work of Frederick Teiwes (1979). According to Harding, these contributions assumed that China's politics, culture, and history are so complex "that they can be understood only by those who have devoted their entire careers exclusively to their analysis" (Harding 1984, 298). Though the analysis does not take on the task of explaining why most sinologists still keep debates about China isolated, the latter suggests that they may still find China a difficult case to compare on some levels. There are good empirical reasons to think that this assumption can be misleading, however. While the Chinese leadership draws on the discourse of China's exceptionalism when it best suits it, ${ }^{27}$ evidence shows that it does not understand the societal and political challenges that China is facing as unique. David Shambaugh (2008) analyzes the CCP's assessment of the challenges facing other party-states in Asia, the Middle East, and Latin America, and post-Soviet states, and claims that such comparisons made on the part of the leadership have shaped the nature of CCP reforms since the 1990s. For instance, following the 2003 Rose Revolution in Georgia, the 2004 Orange Revolution in Ukraine, and the 2005 Lemon Revolution in Kyrgyzstan, the Chinese leadership took action to prevent similar events from occurring on its territory (Brady 2008; Shambaugh 2008). These measures varied from increased Internet censorship and the need for all blogs and websites to be officially registered, to the removal from library bookshelves of books that elaborated too much on China's economic disparities (Yong 2005). In a similar vein, Brady not only claims that the CCP leadership has learned from the mistakes of the Soviet Union and is determined to avoid its fate, but also emphasizes that "Chinese think tanks have been studying the rise and fall of political parties in the non-communist world" (Brady 2008, 180). Such analyses and calculations on the part of Chinese leaders and scholars are based on the assumption that China's contemporary challenges share some similarities with those of other countries at some stages of their respective political development. If the leadership believes that core domestic decisions for China's future ought to be made on the basis of comparisons with other countries, why is China scholarship not more comparative?

\section{Comparative Politics: The Effects of the Discipline's "Democratic Prism"}

Beyond the tendency of scholars of Chinese politics to isolate their own debates, comparative politics has lacked adaptability to adjust its puzzles to changes in empirical reality, including the implications of China's mul- 
tifaceted and uncommon path to development. This lack of adaptability, I believe, stems from a democratic prism in which most comparative politics debates have evolved. By "democratic prism," I refer to scholarly lenses that prioritize the study of phenomena that are inherently connected to democratic settings, and the embrace of democratic lenses to understand social or political reality in a nondemocratic setting. ${ }^{28}$

Reasons for biases against the study of nondemocratic regimes are manifold. Some would emphasize that since the 1970s, we have entered an era of democratization (Huntington 1991) in which remaining authoritarian, post-totalitarian, and totalitarian regimes are quickly disappearing (Diamond 2008). ${ }^{29}$ If it is true that the world is becoming more democratic, ${ }^{30}$ "important" substantive questions about political and social reality have accordingly been determined based on the rule of the majority. Between 1998 and 2008, only one article using China as a case study was published in the American Political Science Review (APSR). ${ }^{31}$ In contrast, 134 used European and North American countries as cases (81.2 percent); ten were based on the study of Latin America (6 percent), seven on African cases (4 percent), seven on other Asian countriesmostly Japan-(4 percent), four on post-Soviet countries (2.4 percent), and three on the Middle East (1.8 percent). Out of 369 case studies published in the American Journal of Political Science (AJPS), not a single article explored the China case. In contrast, 312 focused on Europe and North America (84.5 percent), twenty-seven on Latin America (7.3 percent), fourteen on Post-Soviet states (3.8 percent), eight on Africa (2.2 percent), one on the Middle East ( 0.3 percent), and seven on other Asian countries (1.9 percent). Other political science journals also published a limited number of China articles between 1998 and 2008. Out of 417 case study articles published in the Journal of Politics (JOP), four used China as a case study ( 1 percent), four explored other Asian country cases ( 1 percent), six were based on an African case (1.4 percent), nineteen were based on a Latin American case (4.6 percent), eleven focused on post-Soviet states (2.6 percent), five focused on the Middle East (1.2 percent), and 368 focused on Europe and North America (88.2 percent). (See Table 5.)

Out of 116 case study articles in World Politics, only five used China as a case ( 4.3 percent), and thirteen explored other Asian country cases (11.3 percent); seven focused on Africa (6 percent), twenty-seven on Latin America (23.3 percent), thirty-one on Central and Eastern Europe (26.7 percent), and thirty-one on Western Europe and North America (26.7 percent). Moreover, during that decade, Politics and Society published 168 case study analyses, six of which were on China (3.6 percent), 
Table 5 Case Study Articles by Region in Seven Political Science Journals, 1998-2008 (percentage)

\begin{tabular}{|c|c|c|c|c|c|c|c|}
\hline Journals & $\begin{array}{c}\text { Western } \\
\text { Europe and } \\
\text { North America }\end{array}$ & Africa & $\begin{array}{c}\text { Latin } \\
\text { America }\end{array}$ & $\begin{array}{l}\text { Post- } \\
\text { Soviet } \\
\text { States }\end{array}$ & $\begin{array}{c}\text { Middle } \\
\text { East }\end{array}$ & China & $\begin{array}{c}\text { Asia } \\
\text { (excluding } \\
\text { China) }\end{array}$ \\
\hline \multicolumn{8}{|l|}{ American Political } \\
\hline Science Review & 81.2 & 4 & 6 & 2.4 & 1.8 & 0.6 & 4 \\
\hline \multicolumn{8}{|l|}{ American Journal } \\
\hline of Political Science & 84.5 & 2.2 & 7.3 & 3.8 & 0.3 & 0 & 1.9 \\
\hline Journal of Politics & 88.2 & 1.4 & 4.6 & 2.6 & 1.2 & 1 & 1 \\
\hline World Politics & 26.7 & 6 & 23.3 & 26.7 & 1.7 & 4.3 & 11.3 \\
\hline Comparative Politics & 22.9 & 11.9 & 26 & 16.8 & 7 & 7 & 8.4 \\
\hline Politics and Society & 64.8 & 4.2 & 12.5 & 7.7 & 2.4 & 3.6 & 4.8 \\
\hline \multicolumn{8}{|l|}{ Comparative } \\
\hline Political Studies & 40.6 & 7.5 & 25.2 & 11.2 & 2.4 & 4.9 & 8.4 \\
\hline
\end{tabular}

eight on other Asian countries (4.8 percent), seven on Africa (4.2 percent), twenty-one on Latin America (12.5 percent), thirteen on Central and Eastern Europe (7.7 percent), and 109 on Western Europe and North America (64.8 percent). Comparative Political Studies seems to have published few China articles. Out of 286 case study articles, only fourteen used China as an empirical terrain ( 4.9 percent); ${ }^{32} 116$ articles were based on Western Europe and/or North America (40.6 percent), seventytwo focused on Latin American cases (25.2 percent), thirty-two targeted post-Communist societies (11.2 percent), twenty-four focused on Asian countries other than China (8.4 percent), twenty-one studied African countries ( 7.5 percent), and seven explored Middle Eastern societies (2.4 percent). Comparative Politics published a larger proportion of China articles in the past decade. Between 1998 and 2008, out of 227 identified area-based articles in Comparative Politics, fifty-nine used Latin American country cases ( 26 percent), fifty-two used European countries (22.9 percent), thirty-eight used post-Soviet states, including Russia (16.8 percent), twenty-seven were based on African cases (11.9 percent), sixteen used China as a case ( 7 percent), sixteen used the Middle East ( 7 percent), and nineteen were analyses of other Asian contexts (8.4 percent). While Comparative Politics seems to be giving China studies greater visibility, not only does it constitute an exception among most comparative journals, but also the proportion of China contributions remains smaller than that of most other regions of the world.

Beyond a predominant focus on societies that are democratic or that are democratizing, the majority of publications in these journals centered 
on themes relevant to democracies. For instance, 72.1 percent of APSR's articles published between 1998 and 2008 addressed topics exclusive to democracies $^{33}$ (357 articles out of a total of 495). In contrast, 1 percent of articles explored themes related to both democracies and nondemocratic regimes $^{34}$ (five out of 495), and 1.4 percent addressed a theme exclusive to autocratic regimes. ${ }^{35}$ Similarly, among a total of 634 publications in $A J P S, 78$ percent explored a topic that was exclusively linked to democracy, 0.9 percent focused on themes that pertained to both autocracies and democracies, 0.6 percent were exclusively tied to autocracies, and 20.5 percent of articles addressed a topic that was unrelated to the nature of regimes. Out of 645 articles in JOP, 77 percent explored a theme exclusive to democracies, 2.2 percent addressed a topic related to both autocracies and democracies, 0.7 percent were articles exclusively linked to autocracies, and 20.1 percent were unrelated to regime type. (See Table 6.)

Among a total of 232 publications in World Politics between 1998 and 2008, 56 percent explored themes specifically tied to democracies, 4.8 percent were studies addressing themes related to both democracies and nondemocratic regimes, and 5.6 percent addressed autocracy-related themes exclusively. Of all the publications 33.6 percent covered topics that were unrelated to the nature of regimes. Out of 254 articles published in Comparative Politics, 173 addressed a topic that is uniquely relevant to democracies (68.1 percent), twenty-three were exclusively tied to autocratic regimes ( 9 percent), nineteen were linked to both regime types ( 7.5 percent), and thirty-nine were unrelated to the nature

Table 6 Article Topics Related to Regime Types in Seven Political Science Journals, 1998-2008 (percentage)

\begin{tabular}{|c|c|c|c|c|}
\hline Journals & $\begin{array}{c}\text { Topic } \\
\text { Exclusive to } \\
\text { Democracies }\end{array}$ & $\begin{array}{c}\text { Topic } \\
\text { Exclusive to } \\
\text { Autocratic Regimes }\end{array}$ & $\begin{array}{c}\text { Topic } \\
\text { Related to Both } \\
\text { Democracies and } \\
\text { Autocratic Regimes }\end{array}$ & $\begin{array}{l}\text { Unrelated } \\
\text { Topic }\end{array}$ \\
\hline \multicolumn{4}{|l|}{ American Political } & 25.5 \\
\hline American Journal & 78 & 09 & 06 & 205 \\
\hline Journal of Politics & 77 & 2.2 & 0.7 & 20.1 \\
\hline World Politics & 56 & 5.6 & 4.8 & 33.6 \\
\hline Comparative Politics & 68.1 & 9 & 7.5 & 15.4 \\
\hline $\begin{array}{l}\text { Politics and Society } \\
\text { Comparative }\end{array}$ & 58.1 & 1 & 6 & 34.9 \\
\hline Political Studies & 77 & 1.9 & 2.1 & 19 \\
\hline
\end{tabular}


of regimes (15.4 percent). Out of 215 articles published in Politics and Society, 125 explored a theme exclusive to democracy (58.1 percent), two were unique to autocratic regimes ( 1 percent), thirteen were related to both regime categories ( 6 percent), and seventy-five were unrelated to the latter (34.9 percent). Out of 466 articles published in Comparative Political Studies, 359 addressed a topic exclusive to democracies (77 percent), ten explored a theme related to both democratic and nondemocratic regimes (2.1 percent), nine were exclusively tied to autocracies (1.9 percent), and 89 studied a topic unrelated to the nature of a country's regime (19 percent).

Beyond the assumption that it is of greater relevance to analyze democracies than other regimes in an increasingly democratic world, the study of China may have also been marginalized in the discipline due to assumptions that remaining nondemocratic regimes are hard to analyze on the basis of scientific research criteria (see King, Keohane, and Verba 1994). A sentence in the introduction of a syllabus in 2008 emphasizes the difficulties associated with data gathering in such contexts: "Comparative research is much more difficult in non-democracies and in weakly institutionalized regimes, where the decision-making process is often not readily observable." However, most China scholars would agree that though field research is subject to various forms of political obstacles and restrictions, the latter are not unique to nondemocratic settings (Stogersen and Heimer 2006, 3). Finally, Lieberthal claimed that one of the reasons for the study of China's limited impact on the discipline in the 1980s and throughout the earlier decades lay in political science's quantitative turn and the unavailability of reliable statistical data on the country (Lieberthal 1986, 72). Yet, in a current era of social science research where the "eclectic messy center" (Kohli et al. 1995) has become a model of research design for many comparativists, one would expect more attention to be paid to qualitative analyses of Chinese polity and society. This, however, has not been the case.

The democratic prism in which the discipline is caught has had two implications for the impact of China-focused scholarship on current debates. First, in understudying remaining yet constantly evolving nondemocratic regimes, a wide range of potentially misleading asumptions about the state, party-state relations, as well as state-society interactions characterizing those regimes have been rigidified and considered as truths not only by a large number of comparativists, but also among several China scholars. ${ }^{36}$ For instance, in orienting the debate almost exclusively around conditions for successful democratic transitions, many scholars of comparative politics turned their attention away from the pos- 
sibility that the remaining nondemocratic regimes may not follow a similar path to political development as countries of the third wave have. This requires analyzing the conditions under which nondemocratic regimes have lasted and are likely to last (Way 2005; Bueno de Mesquita et al. 2003; Gandhi and Przeworski 2007; Magaloni 2006; Nathan 2003; Slater 2010). While the recent literature on hybrid regimes has criticized transitology using post-Soviet experiences as an empirical terrain, more ink needs be spilt on the China case. Doing the latter could allow scholars to go beyond the institutional variables that have been commonly emphasized as securing authoritarian regime resilience ${ }^{37}$ and explore how the complexity of central and local government responses to the rise of civil society (i.e., combinations of partial accommodation and targeted repression) may further help ensure the survival of the political establishment (Cai 2008; Perry 2007). ${ }^{38}$

Similarly, Shiping Zheng (1997) emphasizes that scholars have taken too seriously the concept of the party-state where relevant, allowing little analytical space to question whether in some circumstances the party and the state constitute two separate institutional entities. The assumption that the party and the state in China are a single entity serves the purpose of "describ[ing] the Chinese state without a need for further explanation." This assumption is not exclusively shared among those who believe that it is more relevant to study the conditions under which transitions to democracry are successful as opposed to the reasons why authoritarian regimes last. However, the discipline's lack of attention to the complexity of dynamics among nondemocratic leaderships may have facilitated the acceptance of potentially false assumptions.

The discipline's democratic prism has also been manifested in a core assumption underlying the studies of contentious politics scholars. The latter seem to have deductively inferred the types of political opportunity structures for the rise of civil society that authoritarian regimes are likely to have, based on the study of opportunity structures ${ }^{39}$ in liberal-democratic settings. For instance, several studies have treated state repression as an inherent aspect of an autocratic regime's opportunity structure and implicitly assumed that an autocratic state ought to be equated with repressive reaction to collective protests. David Kelly, in his analysis of citizen movements in China's Hu-Wen era, understands the state as constant in "charg[ing] the movements with inciting turmoil in the name of rights protection," and punishing mobilizers across types of collective claims (Kelly 2006, 204). This assumption is not only theoretically questionable but could also be empirically problematic in light of recent developments in China. First, it does not consider the possibility of the state reacting to society 
differently on the basis of the claims underlying resistance (Perry 2001). Second, though there remains a gap between existent laws and the ways in which they are implemented, the Chinese central government is slowly redefining its authority vis-à-vis society; for instance, in July 2008, the Central Committee of the CCP Discipline Inspection Commission, along with three other government agencies, promulgated a new provision prohibiting the abuse of power or force on the part of police officers in their handling of collective demonstrations. ${ }^{40}$

Additionally, the assumption that repression is an inherent aspect of authoritarian regimes' opportunity structure has been illustrated in the questions scholars choose to analyze at the expense of others. Sidney Tarrow (1994), for instance, explores the effects of repression on the likelihood of collective action in nondemocratic societies but does not explore the potential cases in which nondemocratic states may accommodate collective mobilizers and why they would do so. If we were to understand a regime's opportunity structure as lacking coherence and as being complex, authoritarian regimes may provide the space for the representation of some societal interests. This would allow comparativists, including China scholars, to address questions like: Under what conditions is an authoritarian regime more or less likely to repress or accommodate mobilizers? Are these conditions ideational, institutional, or structural? Are there policy areas for which the costs of societal mobilization in an authoritarian regime are low or high?

Second, many comparativists seem to have considered some debates as already over and as such have dismissed some potentially important conceptual and theoretical contributions coming from the study of a constantly evolving nondemocratic polity like China. For instance, recent studies of Chinese corporatism have not been acknowledged as they should in the broader comparative literature on corporatism. Similarly, studies of the Chinese developmental state have yet to find recognition in the discipline. While it is true that debates about the nature of corporatisms and their impact on the political representation of a wide range of interests were predominant in the 1970s and 1980s studies of Latin America, and in the 1990s analyses of the developmental state in South Korea, Taiwan and Japan, the discipline seems to have turned its back on a potentially interesting case of corporatism featuring similar and distinctive features from already existent models in the literature. ${ }^{41}$ The Chinese developmental state appears different from the already existing ones in three ways. First, decentralization has made the pursuit of reforms and growth possible without any dramatic changes in China's regime (Oi 1999). Second, economic policies such as China's campaign to develop 
its Western regions served as tools for state officials to strengthen their hold on the Chinese Communist Party. In other East Asian developmental states, officials did not have to worry about political survival (Shih 2004). Third, the state's control of the economy has differed from that in other East Asian states, taking the form of "local state corporatism"(Oi 1999). By the latter concept, the author refers to a party-state rooted in a Leninist system in which the local governments have the governing capacity and policy tools to conduct industrialization (Oi 1999, 95-96). Local state corporatism, or the decentralization of officials' relations with the private sector, stands in sharp contrast with Japan's unitary government's extensive regulation and planning of the economy as described in the works of Meredith Woo-Cumings (1999) and Chalmers Johnson (1982), and yet it seems to have produced economic development outcomes that were also highly successful. Despite the empirical and conceptual distinctions cited, there seems to have been little appreciation of the Chinese model of the developmental state in my sample of syllabi and in a number of comparative politics journals.

\section{Conclusion}

It is exactly because China has followed a path to development that defies the odds that it should be taken more seriously as an empirical terrain for the purpose of theory testing and building. Obstacles to the visibility of the China case in the discipline are particularly revealing of how comparativists understand the boundaries of comparability or what it means to be "comparative." For China scholars, being comparative has meant studying China from within, by making intracase historical or regional comparisons,${ }^{42}$ hence producing knowledge that is almost exclusively shared among China scholars. While intracase comparisons are fundamental for our engagement with the China field, they should not come at the expense of our theoretical engagement with the broader discipline. The two are not mutually exclusive but rather go hand-in-hand. Being comparative should also involve theoretical engagement with the core debates in comparative politics to make China an integral and instructive case in the discipline.

The democratic prism with which most comparativists have conceived of empirical puzzles has shaped their understanding of what is comparable and worth comparing. As such, some of the core journals in comparative politics have given priority to studies of democratic societies and democracy-related topics and have paid little attention to the recent developments in remaining authoritarian regimes like China. We 
ought to pay closer attention to the institutional features of democratic regimes that may also exist in authoritarian systems-including a complex policymaking process involving various kinds of conflicting interests (Zheng 1997), political parties and elections (Geddes 2005), the tolerance of certain forms of social mobilization or the implementation of institutional mechanisms meant to address societal demands-and the ways in which these institutions help autocratic regimes survive. The line between democratic and nondemocratic regimes can be spurious, and political scientists have so far missed opportunities for incorporating China findings into a broader discussion about regime transformation.

Marie-Eve Reny is a PhD candidate in the Department of Political Science at the University of Toronto and a research fellow at the Munk School of Global Affairs. Her work centers on state-society relations, contentious politics, and the politics of religion in mainland China. She has published in Ethnic and Racial Studies.

\section{Notes}

I would like to thank Daniel A. Bell, Jacques Bertrand, Zsuzsa Csergo, Edward Friedman, Jean-François Huchet, Kate Korycki, Barry Naughton, Narendra Subramanian, Lucan A. Way, and Joseph Wong for their questions and invaluable feedback on earlier versions of the project. I am also grateful to five anonymous reviewers as well as the editor of the Journal of East Asian Studies, Stephen Haggard, for their helpful comments on the manuscript. I bear sole responsibility for the arguments advanced in the article. An earlier version of the review essay was presented at the American Political Science Association (APSA) annual meeting on September 3, 2010, in Washington, DC.

1. The study of Latin America was crucial to the emergence of the literature dependency and modernization theories (Cardoso and Faletto 1979). It also constituted a central empirical terrain for the development of the literature on corporatism (O'Donnell, Schmitter, and Whitehead 1986). The study of African societies was crucial to the evolution of the state (Herbst 2000), regime transitions (Bratton and Van de Walle 1997), ethnic conflict and politics (Laitin 1992; Horowitz 1985), and the politics of development literatures. Finally, the study of post-Soviet states gave rise to a new literature on hybrid regimes (Shevtsova and Eckert 2001; Levitsky and Way 2002; Diamond 2002; Bunce 2003), questioning already existent regime categories. It also left significant marks in the literature on identity politics, ethnic conflict, and violence. Among several other important contributions are those of Beissinger (2002), Brubaker (2006), Csergo (2007), Hale (2008), Laitin (1998), and Schatz (2004).

2. It is because epistemic communities play an important role in policymaking (Adler and Haas 1992) that they also tend to grow according to the problems that governments expect them to analyze.

3. Opportunities to do research in China opened up in the 1980s (Stogersen and Heimer 2006). 
4. The terms China scholarship, scholars of Chinese politics, sinologists, and China scholars are used interchangeably in the context of this analysis.

5. A random selection of syllabi would have been impossible to do without access to an already consolidated and comprehensive database of comparative politics syllabi responding to each of my selection criteria. In the absence of any possibility for random selection, online data gathering appeared as the secondbest option.

6. For the most recent national university rankings, see http://colleges .usnews.rankingsandreviews.com/best-colleges.

7. Among them were Gallagher's "'Reform and Openness': Why China's Economic Reforms Have Delayed Democracy" (2002), O'Brien's "Rightful Resistance" (1996), Dickson's “Threats to Party Supremacy” (2003), Pei's “The Dark Side of China's Rise" (2006b), and Shi's Political Participation in Beijing (1997).

8. It is true that comparing China studies with literatures exploring regions of the world composed of many countries, like Latin America and Africa, might overstate my claim about the low visibility of China studies in comparative politics. However, to the extent that comparativists tend to treat particular countries as a case independent of the size and diversity of the country, the experiences of large countries like China might receive less attention than their importance in the world warrants.

9. I have excluded Western Europe from this comparison, because to assess the visibility of China in a discipline that has legacies of eurocentrism, findings may be more revealing if the study of China is compared with that of other economically developing and/or politically changing areas of the world. What makes the low visibility of China studies more surprising is not that its impact on comparative politics is much smaller than that of studies of Western Europe and North America, but that the analysis of several developing areas has had much greater influence on the discipline than that of China.

10. The same applies to other world regions or countries covered in such kinds of syllabi. For instance, in a 2009 University of Wisconsin course outline, different chapters from Michael J. Sodaro's Comparative Politics: A Global Introduction (2008) were included in sections of the syllabus on the United Kingdom, Germany, Brazil, and Russia.

11. The same is also true of studies of other areas. Significant contributions to the study of regions like Latin America and Eastern Europe have been made by comparativists who were not claiming to be particular experts of such areas. Przeworski's Democracy and the Market: Political and Economic Reforms in Eastern Europe and Latin America (1991) illustrates this well. However, the above two regions have had much greater visibility in the field than China has.

12. Some would argue that beyond the sources listed here, Southeast Asia contributions remain limited. While this may very well be the case, these few Southeast Asia sources were consistently listed in comparative politics syllabi, which suggests that they are recognized as classics in the discipline. This, however, does not yet seem to be the case for any China contribution.

13. Please note that the following examples are only a few among several others.

14. Scholars like Vogel (2006) have partly attributed Japan's inability to move 
from a coordinated market economy (CME) to a US-type model of liberal market economy (LME) to the social norms that pervade the Japanese bureaucracy.

15. However, it is worth highlighting that neither Montinola nor Weingast are China specialists. Moreover, while Qian's area of specialization is China, the author is not a political scientist but an economist.

16. In saying so, I do not wish to suggest that it is better to publish in subfield journals than area journals but emphasize that there may be missed opportunities for greater visibility and impact in exclusively targeting an areabased audience.

17. I choose not to name these scholars but wish to explain how I have selected them. I have selected five Chinese politics syllabi online on the basis of two criteria. First, the courses needed to be general and cover a wide range of themes pertaining to Chinese politics, from regime transition or stability to social movements and revolutions. Second, the syllabi could not exclusively assign textbooks but needed to have a relatively exhaustive list of China publications. On that basis, I looked for the most recurrent authors within and across syllabi. I excluded from my sample China scholars who are not political scientists. I focused my attention on scholars who had four or more publications across those five syllabi and who appeared on at least three of the latter.

18. These two scholars are also among the ones whose work was acknowledged in my sample of syllabi.

19. It is worth noting, however, that among the sixteen publications in theme-based journals for scholar D, four of them came from business journals and at least six came from international relations (IR) journals. Hence, though they were theme-oriented publications, they were not necessarily targeting an audience of comparativists. The same reality applies to scholar G, for whom the twenty-three theme-oriented publications included articles published in journals pertaining to economics, the environment, and IR.

20. The means by which I selected Latin Americanists and scholars of other regions were the same as the ones I used for China scholars.

21 . For instance, if they happen to be doing a comparative study of country $\mathrm{X}$ and China and need to read secondary material about the latter. However, it is possible that searching by keywords in online article databases may have provided comparativists with greater opportunities for skimming publications about other areas on themes of relevance.

22. The book primarily addresses the following question: Why was there a time lag between the commitment by Chinese leaders to reduce the size of the government and reorient its functions for the pursuit of market reforms, and the actual conversion of those ideas into policy?

23. Encarnacion (2000) claims that the preexistent structural conditions that persist during a transition from one regime to another (in his study, democratic) help test the health of the new regime (he referred to democracy, more specifically). Along similar lines, Geddes (1995) stresses that actors may exploit advantages from the old regimes they may still have in order to control the transition process and for purposes of future success. While it remains unclear whether China is undergoing a transition, and if so what to, the general idea underlying Geddes's point can easily be reconciled with elements of Perry's analysis. 
24. Perry $(2007,20)$ stresses that "under revolutionary authoritarianism of the PRC, mass mobilization has been a hallmark of state-society relations."

25. This term comes from O'Brien and Li's Rightful Resistance (2006).

26. Perry (2007) makes such a comparison only in a paragraph on the penultimate page of her article.

27. I attended a number of bilateral meetings involving representatives of the Chinese Ministry of Foreign Affairs in 2006, during which Chinese counterparts typically drew on some of their distinctive features to justify the slow pace of political, and more particularly human rights-related, reforms.

28 . The latter would be best represented by attempts to understand the conditions under which nondemocratic countries are likely to become democratic, or to predict when they will become so.

29. Pye (1990) also saw the world as facing a crisis of authoritarianism but anticipated a significant number of transitions to semidemocratic or semiauthoritarian regimes that would not conform to conventional typologies.

30. Diamond (2008) claims that in 1974, almost three-quarters of all countries were nondemocratic and that today, about 60 percent are democracies. This view is worth questioning to the extent that it is based on a procedural definition of democracy and refers to a wide range of countries that are at different stages of their political development, many of which are more soft-authoritarian or semidemocratic than actually "democratic." In contrast, Magaloni and Kricheli (2010) claim that the spread of democracy also came with that of one-party regimes, including single-party and dominant-party autocracies.

31 . I used the fact that a country or a particular set of countries was introduced in the title or abstract of articles as a way of identifying whether or not studies were based on particular country cases. Given that some of the publications did not use case studies, the sum of the listed numbers does not constitute the total number of articles published in each journal between 1998 and 2008.

32. I identified case studies based on the title of each publication. I treated as case study articles the ones whose title included the name of countries or locations within countries (i.e., cities).

33. I have excluded from that category articles pertaining to themes like democracy as an international norm or the existence of a transnational civil society, which I considered more related to international relations than to domestic politics.

34. I have categorized journal articles as addressing a democracy or nondemocratic regime-related theme based on the content of their title. For instance, a 2002 APSR article by Gretchen Helmke, "The Logic of Strategic Defection: Court-Executive Relations in Argentina Under Dictatorship and Democracy," was categorized as exploring a topic related to both democracy and autocratic regime. An 2005 APSR article by Orit Kedar,"When Moderate Voters Prefer Extreme Parties: Policy Balancing in Parliamentary Elections," was categorized as addressing a topic exclusive to democracies.

35. 25.5 percent of $A P S R$ 's articles during that period were difficult to categorize as related to either democracy or authoritarianism. Many such articles explored a theme pertaining to international relations or political theory.

36. Some sinologists have also been influenced by the democratic prism in the discipline. This has impacted how they have studied China, predominantly 
emphasizing the problems in the current regime as opposed to the reasons why the regime has defied the odds and why liberal democracy has so far remained unlikely. Recent scholarship within China studies has attempted to transcend this bias by addressing the causes of regime resilience (Nathan 2003; Shambaugh 2008; Brady 2008) or the reasons for China's trapped transition (Pei 2006a).

37. The few scholars who have taken on the task of explaining autocratic resilience have done so predominantly using institutional variables. Way (2005, 232) emphasizes that "effective coercion and the capacity of leaders to keep their allies in line" are crucial to authoritarian rule resilience. Nathan $(2003,11) \mathrm{em}$ phasizes among other factors the growing role of meritocracy in the promotion of elites as well as "the separation of . . . spheres of authority" between political institutions. Alexeyeva (1985), Bertrand (2004), and Linz (2000), in the context of very different studies, emphasize authoritarian regimes' ability to co-opt parts the opposition.

38 . In a similar vein, Magaloni and Kricheli $(2010,126)$ have recently proposed avenues for future research on one-party regimes, stressing among other core questions, the need to explore in greater depth the "strategies dictators follow to appease simultaneous threats to their stability from within the elites and from within the masses." As far as China is concerned, it is worth noting that the Chinese government has in recent years adopted a series of reforms to deal with growing instances of social protests in order to better ensure transparency and accountability. For instance, in June 2009, Hu Jintao signed a decree to implement a law whose purpose is to facilitate the transparent handling of disputes pertaining to the mismanagement of rural land contracts. The Law on the Mediation and Arbitration of Rural Land Contract Disputes took effect in January 2010. It makes local governments responsible for forming arbitration committees at the county and municipal levels, whose purpose is to hear disputes and manage the overall arbitration process. See Xinhua News Agency, "China's Legislature Eyes Stability with Law on Rural Land Disputes Mediation," June 27, 2009. In July 2008, the Central Committee of the CCP Discipline Inspection Commission, along with three other government agencies, promulgated a new provision prohibiting the abuse of power or force on the part of police officers in their handling of collective demonstrations. See Caijing 2008.

39. Tarrow (1994) defines a political opportunity structure as the dimension of the polity that generates incentives for actors to organize collective action by shaping their calculations of potential success or failure.

40. Caijing 2008.

41. There are exceptions to the rule, which include Wong (2004) and Shih (2004).

42. For intracase historical comparisons, see some of Perry's studies, including Challenging the Mandate of Heaven (2001) and her analysis of the enduring features of the Chinese state's Maoist tactics of mobilization (Perry 2007). Regional comparisons have been more common in studies of economic development and inequality in China, many of which have sought to explain the causes and effects of regional variance in development outcomes (Wang, $\mathrm{Hu}$, and Kang 2000). 


\section{References}

Adler, Emanuel, and Peter M. Haas. 1992. "Conclusion: Epistemic Communities, World Order, and the Creation of a Reflective Research Program." International Organization 46, 1: 367-390.

Alexeyeva, Ludmilla. 1985. Soviet Dissent: Contemporary Movements for $\mathrm{Na}$ tional, Religious and Human Rights. Middletown, CT: Wesleyan University Press.

Beissinger, Mark R. 2002. Nationalist Mobilization and the Collapse of the Soviet State. Cambridge: Cambridge University Press.

Bertrand, Jacques. 2004. Nationalism and Ethnic Conflict in Indonesia. Cambridge: Cambridge University Press.

Blecher, Marc J., and Vivienne Shue. 1996. Tethered Deer: Government and Economy in a Chinese County. Stanford: Stanford University Press.

Brady, Anne-Marie. 2008. Marketing Dictatorship: Propaganda and Thought Work in Contemporary China. Lanham, MD: Rowman \& Littlefield.

Bratton, Michael, and Nicolas van de Walle. 1997. Democratic Experiments in Africa: Regime Transitions in Comparative Perspective. Cambridge: Cambridge University Press.

Brubaker, Rogers. 2006. Nationalist Politics and Everyday Ethnicity in a Transylvanian Town. Princeton: Princeton University Press.

Bueno de Mesquita, Bruce, A. Smith, R. M. Siverson, and J. D. Morrow. 2003. The Logic of Political Survival. Cambridge: MIT Press.

Bunce, Valerie. 2003. "Rethinking Recent Democratization: Lessons from the Postcommunist Experience.” World Politics 55, 2: 167-192.

Cai, Hongbin, and Daniel Treisman. 2006. "Did Government Decentralization Cause China's Economic Miracle?" World Politics 58, 4: 505-535.

Cai, Yongshun. 2008. "Local Governments and the Suppression of Popular Resistance in China." The China Quarterly 193: 24-42.

Caijing. 2008. "Si bumen fa wenming quexin fang gongzuo wenze zhidu" [Four departments issued measures to be taken for a clear system of accountability], July 25. Available at www.caijing.com.cn/2008-07-25/100076447.html (accessed July 15, 2009).

Cardoso, Fernando Henrique, and Enzo Faletto. 1979. Dependency and Development in Latin America. Translated by Marjory Urquidi. Berkeley: University of California Press.

Csergo, Zsuzsa. 2007. Talk of the Nation: Language Conflict in Romania and Slovakia. Ithaca: Cornell University Press.

Dahl, Robert A. 1971. Polyarchy: Participation and Opposition. New Haven: Yale University Press.

Diamond, Larry. 2002. "Thinking About Hybrid Regimes." Journal of Democracy $13,2: 21-35$.

- 2008. The Spirit of Democracy. New York: Times Books.

Dickson, Bruce J. 2003. "Threats to Party Supremacy." Journal of Democracy $14,1: 27-35$.

Encarnacion, Omar G. 2000. "Review: Beyond Democratic Transition: The Politics of Democratic Consolidation." Comparative Politics 32, 4: 479-498. 
Evans, Peter. 1995. Embedded Autonomy: States and Industrial Transformation. Princeton: Princeton University Press.

Friedman, Edward, and Joseph Wong. 2009. "Learning to Lose: Dominant Parties, Dominant Party Systems, and Their Transitions." In Political Transitions in Dominant Party Systems: Learning to Lose, ed. Edward Friedman and Joseph Wong. London: Routledge.

Gallagher, Mary E. 2002. “'Reform and Openness': Why China's Economic Reforms Have Delayed Democracy." World Politics 54: 338-372.

Gandhi, Jennifer, and Adam Przeworski. 2007. "Dictatorial Institutions and the Survival of Autocrats." Comparative Political Studies 40: 1279-2301.

Geddes, Barbara. 1995. "A Comparative Perspective on the Leninist Legacy in Eastern Europe.” Comparative Political Studies 28, 2: 239-274.

- 2005. "Why Parties and Elections in Authoritarian Regimes?" Presentation at the annual meeting of the American Political Science Association, Washington, DC.

Gilley, Bruce. 2011. "State Dominance and Liberalizing Authoritarianism in China: Kicking Society Back Out." Journal of Contemporary China (forthcoming).

Hale, Henry E. 2008. The Foundations of Ethnic Politics: Separatism of States and Nations in Eurasia and the World. Cambridge: Cambridge University Press.

Harding, Harry. 1984. "The Study of Chinese Politics: Toward a Third Generation of Scholarship." World Politics 36, 2: 284-307.

Herbst, Jeffrey. 2000. States and Power in Africa: Comparative Lessons in Authority and Control. Princeton: Princeton University Press.

Horowitz, Donald L. 1985. Ethnic Groups in Conflict. Berkeley: University of California Press.

Huang, Jing. 2000. Factionalism in Chinese Communist Politics. Cambridge: Cambridge University Press.

Huntington, Samuel P. 1968. Political Order in Changing Societies. New Haven: Yale University Press.

-1991. The Third Wave: Democratization in the Twentieth Century. Norman: University of Oklahoma Press.

Johnson, Chalmers. 1982. MITI and the Japanese Miracle. Stanford: Stanford University Press.

Katzenstein, Peter J. 1978. Between Power and Plenty: Foreign Economic Policies of Advanced Industrial States. Madison: University of Wisconsin Press.

Kelly, David. 2006. "Citizen Movements and China's Public Intellectuals in the Hu-Wen Era." Pacific Affairs 79, 2: 183-204.

King, Gary, Robert O. Keohane, and Sidney Verba. 1994. Designing Social Inquiry: Scientific Inference in Qualitative Research. Princeton: Princeton University Press.

Kohli, Atul, et al. 1995. "The Role of Theory in Comparative Politics: A Symposium." World Politics 48, 1: 1-49.

Laitin, David D. 1992. Language Repertoire and State Construction in Africa. Cambridge: Cambridge University Press.

. 1998. Identity in Formation: The Russian-Speaking Populations in the Near Abroad. Ithaca: Cornell University Press. 
Levitsky, Stephen, and Lucan A. Way. 2002. "The Rise of Competitive Authoritarianism." Journal of Democracy 13, 2: 51-65.

Lieberthal, Kenneth. 1986. "China and Political Science." PS: Political Science and Politics 19, 1: 70-78.

Linz, Juan. 2000. Totalitarian and Authoritarian Regimes. Boulder: Lynne Rienner.

Lü, Xiaobo. 2000. "Booty Socialism, Bureau-preneurs, and the State in Transition: Organizational Corruption in China." Comparative Politics 32, 3: 273-294.

Magaloni, Beatriz. 2006. "The Comparative Logic of Autocratic Survival." Manuscript.

Magaloni, Beatriz, and Ruth Kricheli. 2010. "Political Order and One-Party Rule." Annual Review of Political Science 13: 123-143.

Manion, Melanie. 2006. "Democracy, Community, Trust: The Impact of Elections in Rural China." Comparative Political Studies 39: 301-324.

Montinola, Gabriella, Yingyi Qian, and Barry R. Weingast. 1995. "Federalism, Chinese Style: The Political Basis for Economic Success in China." World Politics 48, 1: 50-81.

Moore, Barrington. 1966. Social Origins of Dictatorship and Democracy: Lord and Peasant in the Making of the Modern World. Boston: Beacon Press.

Nathan, Andrew. 1973. "A Factionalism Model for CCP Politics." China Quarterly 53, 1: 34-66.

- 2003. “Authoritarian Resilience.” Journal of Democracy 14, 1: 6-17.

North, Douglass. 1990. Institutions, Institutional Change and Economic Performance. Cambridge: Cambridge University Press.

O’Brien, Kevin J. 1996. "Rightful Resistance." World Politics 49, 1: 31-55.

O'Brien, Kevin J., and Lianjiang Li. 2006. Rightful Resistance in Rural China. New York: Cambridge University Press.

O'Donnell, Guillermo, Philippe C. Schmitter, and Laurence Whitehead. 1986. Transitions from Authoritarian Rule: Latin America. Baltimore: Johns Hopkins University Press.

Oi, Jean C. 1992. "Fiscal Reform and the Economic Foundations of Local State Corporatism in China." World Politics 45: 99-126.

- 1999. Rural China Takes Off: Institutional Foundations of Economic Reform. Berkeley: University of California Press.

Olson, Mancur. 1971. The Logic of Collective Action: Public Goods and the Theory of Groups. Cambridge: Harvard University Press.

- 1996. "The Economics of Autocracy and Majority Rule: The Invisible Hand and the Use of Force." Journal of Economic Literature 34: 72-96.

Pei, Minxin. 2006a. China's Trapped Transition: The Limits of Developmental Autocracy. Cambridge: Harvard University Press.

- 2006b. "The Dark Side of China's Rise." Foreign Policy, February 17.

Perry, Elizabeth J. 2001. Challenging the Mandate of Heaven: Social Protest and State Power in China. Armonk: NY: M. E. Sharpe.

. 2007. "Studying Chinese Politics: Farewell to Revolution?" China Journal 57: 1-22.

Pierson, Paul, and Theda Skocpol. 2002. "Historical Institutionalism in Contemporary Political Science." In Political Science: The State of the Discipline, ed. Ira Katznelson and Helen V. Milner. New York: W. W. Norton. 
Popkin, Samuel. 1979. The Rational Peasant: The Political Economy of Rural Society in Vietnam. Berkeley: University of California Press.

Przeworski, Adam. 1991. Democracy and the Market: Political and Economic Reforms in Eastern Europe and Latin America. New York: Cambridge University Press.

Przeworski Adam, and Fernando Limongi. 1993. "Political Regimes and Economic Growth.” Journal of Economic Perspectives 7, 3: 51-69.

Pye, Lucian. 1981. The Dynamics of Chinese Politics. Cambridge, MA: Oelgeschlager, Gunn \& Hain.

. 1990. "Political Science and the Crisis of Authoritarianism." American Political Science Review 84, 1: 3-19.

Sartori, Giovanni. 1991. "Comparing and Miscomparing." Journal of Theoretical Politics 3: 243-257.

Schatz, Edward. 2004. Modern Clan Politics: The Power of Blood in Kazakhstan and Beyond. Seattle: University of Washington Press.

Scott, James C. 1976. The Moral Economy of the Peasant. New Haven: Yale University Press.

- 1985. Weapons of the Weak: Everyday Forms of Peasant Resistance. New Haven: Yale University Press.

Shambaugh, David. 2008. China's Communist Party: Atrophy and Adaptation. Berkeley: University of California Press.

Shevtsova, Liliia Fedorovna, and Mark H. Eckert. 2001. "Russia's Hybrid Regime." Journal of Democracy 12, 4: 65-70.

Shi, Tianjian. 1997. Political Participation in Beijing. Cambridge: Harvard University Press.

Shih, Victor. 2004. "Development, the Second Time Around: The Political Logic of Developing Western China." Journal of East Asian Studies 4, 3: 427-451.

Shirk, Susan L. 1993. The Political Logic of Economic Reform in China. Berkeley: University of California Press.

Skocpol, Theda. 1979. States and Social Revolutions: A Comparative Analysis of France, Russia and China. New York: Cambridge University Press.

. 1995. Social Policy in the United States. Princeton: Princeton University Press.

Slater, Dan. 2010. Ordering Power: Contentious Politics and Authoritarian Leviathans in Southeast Asia. Cambridge: Cambridge University Press.

Sodaro, Michael J. 2008. Comparative Politics: A Global Introduction. London: McGraw-Hill.

Solinger, Dorothy J. 1991. From Lathes to Looms: China's Industrial Policy in Comparative Perspective, 1979-1982. Stanford: Stanford University Press.

Stogersen, Stig and Maria Heimer. 2006. "Introduction." In Doing Fieldwork in China, ed. Stig Stogersen and Maria Heimer. Honolulu: University of Hawai'i Press.

Tarrow, Sidney. 1994. Power in Movement: Social Movements, Collective Action and Politics. Cambridge: Cambridge University Press.

Teiwes, Frederick C. 1979. Politics and Purges in China. White Plains, NY: M. E. Sharpe. 
Treisman, Daniel. 2000. "The Causes of Corruption: A Cross-national Study." Journal of Public Economics 76, 3: 399-458.

Tsai, Kellee S. 2006. "Adaptive Informal Institutions and Endogenous Institutional Change in China." World Politics 59: 116-141.

U.S. News \& World Report. "Best Colleges 2010," http://colleges.usnews.rankings andreviews.com/best-colleges (accessed June 5, 2010).

Vogel, Steven K. 2006. Japan Remodeled: How Government and Industry Are Reforming Japanese Capitalism. Ithaca: Cornell University Press.

Wade, Robert. 2000. Governing the Market: Economic Theory and the Role of the Government in East Asian Industrialization. Princeton: Princeton University Press.

Wang, Shaoguang, Angang Hu, and Xiaoguang Kang. 2000. The Political Economy of Uneven Development: The Case of China. Armonk, NY: M. E. Sharpe (East Gate Books).

Way, Lucan A. 2005. "Authoritarian State Building and the Sources of Regime Competitiveness in the Fourth Wave: The Cases of Belarus, Moldova, Russia and Ukraine." World Politics 7, 2: 231-261.

Weyland, Kurt. 1998. "The Politics of Corruption in Latin America. " Journal of Democracy 9, 2: 108-121.

Whitson, William. 1973. The Chinese High Command: A History of Communist Military Politics, 1927-1971. London: Macmillan.

Wong, Joseph. 2004. "The Adaptive Developmental State in East Asia." Journal of East Asian Studies 4, 3: 345-362.

Woo-Cumings, Meredith. 1999. The Developmental State. Ithaca: Cornell University Press.

Yang, Dali L. 2004. Remaking the Chinese Leviathan: Market Transition and the Politics of Governance in China. Stanford: Stanford University Press.

Yong Ding. 2005. "China's Color-Coded Crackdown." Foreign Policy, October 18.

Zheng, Shiping. 1997. Party vs. State in Post-1949 China: The Institutional Dilemma. Cambridge: Cambridge University Press. 


\title{
TTTHE BROWN JOURNAL OF WORLD AFFAIRS
}

\author{
Fall/Winter 2010 Volume XVII Issue 2
}

\section{POLITICAL INSTABILITY in LATIN AMERICA}

\section{THE GLOBAL WATER CRISIS}

\section{URBANIZATION of the MIDDLE EAST}

\section{Past Contributors}

PROMINENT ACADEMICS: MADELEINE ALBRIGHT • JOHN BOLTON • JIMMY CARTER • NOAM CHOMSKY. • MIKHAIL GORBACHEV • RICHARD HOLBROOKE • ROBERT JERVIS • JOHN MCCAIN • JOSEPH S. NYE, JR. • JEFFREY SACHS • JOSEPH STIGLITZ • PAUL WOLFOWITZ • FAREED ZAKARIA FORMER LEADERS OF: AUSTRIA • BRAZIL • CHILE • CZECH REPUBLIC • FRANCE • HONG KONG • IRAN •ISRAEL •ITALY •NATO • NORWAY • SOUTH AFRICA • WHO

\section{Subscribe now for only $\$ 20.95$ a year}

WATSON INSTITUTE For Subscriptions and advertisements visit bjwa org 回回 田

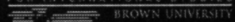
Brown Journal of World Affairs | contact@bjwa.org 